www.volsu.ru

DOI: http://doi.org/10.15688/nav.jvolsu.2017.2.7

UDC $903.05+903.2+904$

LBC 63.4(2)

\title{
FINDS FROM SHIROKY BUERAK SETTLEMENT
}

\author{
Leonard F. Nedashkovsky \\ Kazan (Volga region) Federal University, Kazan, Russian Federation
}

\begin{abstract}
Marat B. Shigapov
Institute of Archaeology named after A.Kh. Khalikov of the Academy of Sciences of the Republic of Tatarstan, Kazan, Russian Federation
\end{abstract}

\begin{abstract}
The article deals with wearing-apparel components, mirrors, objects of arms, horse equipment, daily life, trade and mass material, including pottery of the second half of the $13^{\text {th }}-14^{\text {th }} \mathrm{cc}$. from Shiroky Buerak settlement situated in periphery of the Golden Horde city Ukek in Saratov district of Saratov region and studied by expedition of Kazan University under supervision of L.F. Nedashkovsky in 1996 and 2001-2002. Numismatic finds from the site, which covered area more than $6.8 \mathrm{ha}$ and had the cultural layer with more than $60 \mathrm{~cm}$ width, belong to the Golden Horde mintage of the last third of the $13^{\text {th }} \mathrm{c}$. - beginning of the 1360s. Wearing-apparel components are represented by belt bracket, the armament - by fragment of bronze mace-head, horse equipment - by bit, cinch buckles and harness rings, clothes details - by button and little bell, articles of trade - by weight-seal. The daily life objects analyzed in the article include rivets, handle, fragments of vessels, piece of copper sheet, fragments of castiron cauldrons, iron bucket handle, sickle, locks, bronze coupling and fragment of bone handle of knifes, ram's knucklebone with aperture, poured with lead, awl, knifes, nails. Overall data on the mass archaeological material, including pottery wares, found on the settlement, represented by spindle-whorl, Golden Horde, Old Russian, Mordvin wares, fragments of the Trebizond amphorae and glazed vessels, is provided in the article. Morphological features of wares are examined in the article on the basis of typology with involvement of the broad comparative background of materials of synchronous monuments. This complex characterizes material culture of the Golden Horde village of the Lower Volga region, which, judging by the published materials, differed from material culture of city and town, situated nearby.
\end{abstract}

Key words: settlements, rural sites, the Golden Horde, the Lower Volga region, the regions of Uvekskoe site, material culture, individual finds, pottery.

Citation. Nedashkovsky L.F., Shigapov M.B., 2017. Finds from Shiroky Buerak Settlement. The Lower Volga Archaeological Bulletin, vol. 16, no. 2, pp. 116-130. (in Russian).

УДК 903.05+903.2+904

ББК 63.4(2)

\section{НАХОДКИ С СЕЛИЩА ШИРОКИЙ БУЕРАК}

\author{
Леонард Федорович Недашковский \\ Казанский (Приволжский) федеральный университет, г. Казань, Российская Федерация
}

\section{Марат Баязитович Шигапов}

Институт археологии им. А.Х. Халикова Академии наук Республики Татарстан, г. Казань, Российская Федерация

\footnotetext{
Аннотация. В статье рассматриваются украшения, зеркала, предметы вооружения, конского снаряжения, повседневного быта, торговли и массовый материал, в том числе керамика с селища Широкий Буерак второй половины XIII - XIV в., располагающегося в округе золотоордынского города Укека в Саратовском районе Саратовской области и изучавшегося в 1996 и 2001-2002 гг. экспедицией Казанского университета под
} 
руководством Л.Ф. Недашковского. Монетные находки с памятника, имеющего площадь более 6,8 га и мощность культурных напластований более 60 см, относятся к золотоордынской чеканке последней трети XIII начала 60-х гг. XIV в. Украшения представлены поясной накладкой, предметы вооружения - фрагментом бронзового навершия булавы, конское снаряжение - удилами, подпружными пряжками и кольцами от сбруи, детали одежды - пуговицей и бубенчиком, предметы торговли - грузиком-пломбой. Из предметов быта в статье привлечены заклепки, ушко, фрагменты сосудов, обломок листа, фрагменты чугунных котлов, железные ручка ведра, серп, замки, бронзовая муфта и фрагмент костяной рукояти ножа, бараний астрагал с отверстием, залитым свинцом, шило, ножи, гвозди. В статье приводятся общие данные о массовом археологическом материале, в том числе о керамических изделиях, найденных на селище, представленных напряслом, золотоордынской, древнерусской, мордовской посудой, фрагментами трапезундских амфор и поливных сосудов. Морфологические особенности изделий рассматриваются в статье на основе типологии с привлечением широкого сравнительного фона материалов синхронных памятников. Данный комплекс характеризует материальную культуру золотоордынского села Нижнего Поволжья, которая, судя по публикуемым материалам, отличалась от материальной культуры крупного и малого городов, расположенных неподалеку.

Ключевые слова: селища, сельские поселения, Золотая Орда, Нижнее Поволжье, округа Увекского городища, материальная культура, индивидуальные находки, керамика.

Цитирование. Недашковский Л. Ф., Шигапов М. Б., 2017. Находки с селища Широкий Буерак // Нижневолжский археологический вестник. Т. 16, № 2. С. 116-130.

Селище Широкий Буерак имеет площадь более 6,8 га и мощность культурных напластований более 60 см. Данное сельское поселение датируется по найденным предметам второй половиной XIII - XIV в.; монетные находки с памятника относятся к золотоордынской чеканке последней трети XIII - начала 60-х гг. XIV в. [Недашковский, 2000, с. $110,121-122$, рис. $31,41-42$; 2012 , с. 104 106,108 , рис. 2,2 ; Nedashkovsky, 2004, p. $72-$ $73,78-79,246,250$, fig. 83,41-42, 88, tab. 7-9].

Научное исследование селища осуществлялось археологической экспедицией Казанского университета 1996 и 2001-2002 гг., возглавлявшейся Л.Ф. Недашковским. В 1996 г. осуществлялись разведки, а в 2001-2002 гг. - раскопки поселения (рис. 1).

Рассматриваемый комплекс характеризует материальную культуру золотоордынского села Нижнего Поволжья, которая, судя по публикуемым материалам, отличалась от материальной культуры крупного и малого городов, расположенных неподалеку.

Приведем описание предметов материальной культуры по категориям.

Накладка. С памятника происходит бронзовая литая поясная накладка-лунница с тремя округлыми выступами (рис. 2,1). Изделие, имеющее декоративные скосы к краям, крепилось с помощью двух шпеньков; общие размеры накладки - $15 \times 16$ мм, толщина - 3 мм. Согласно результатам спектраль- ного анализа она была отлита из оловянистой бронзы [Недашковский, 2010, с. 147-150, № 151]. Поясные накладки в форме лунниц характерны для раннеджучидской торевтики [Крамаровский, 2001, с. 37-50, рис. 14,9,14, $15,18,7-13,21,9]$.

Зеркала. На селище найдены фрагменты 12 литых бронзовых зеркал (рис. 2,2-13). Нами принята следующая классификационная система: отделы выделены по форме бортика, а типы - по изображению на зеркале. Нумерация типов дается по ранее опубликованным работам одного из авторов статьи [Недашковский, 2000, с. 48-67; Недашковский, Ракушин, 1998, с. 87-108].

Отдел А. С узким высоким бортиком (рис. 2,2-4).

Тип 1 (1 экз.). Зеркало с изображением двух плывущих друг за другом рыб диаметром 7,3 см (рис. 2,2). Изделие, согласно данным спектрального анализа, было отлито из оловянистой бронзы [Недашковский, 2010, c. 147-149, 151, № 163]. Близкие зеркала с изображением двух рыб достаточно широко представлены в Нижнем и Среднем Поволжье [Железчиков, Кутуков, 1998, с. 139, рис. 4,1,3; Круглов, Клепиков, 1993, с. 139, рис. 1,4; Недашковский, 2000, с. 49-50, рис. 9,1-2; Полякова, 1996, с. 232-233, рис. 74,6; Руденко, 2004 , с. 118 , рис. 18,4 , фото 3]. Подобные изделия известны в позднекочевнических древностях Восточной Европы второй половины 
XIII - XIV в. [Федоров-Давыдов, 1966, с. 82, Н1; Шнайдштейн, 1979, с. 67, рис. 4,4], причем в кургане 108 (погребение 2) могильника Бахтияровка III зеркало данного типа [Кригер, 1985, рис. 155-156] было найдено с монетами Узбека (Сарай ал-Махруса 722 г.х., Сарай 731 г.х.), в материалах Хакасско-Минусинской котловины, Отрара XIII-XIV вв. [Акишев, Байпаков, Ерзакович, 1987, с. 195, рис. 85,4 ; Байпаков, 1990 , с. 144 , рис. 4 ], а также Средней Вятки.

Тип 3 (1 экз.). Зеркало с расплывчатыми изображениями по окружности четырех сидящих человеческих фигур, разделенных четырьмя драконами; с выпуклым валиком, разделяющим зеркало на периферийную и центральную части (рис. 2,3). Данный экземпляр имел диаметр около $8 \mathrm{~cm}$, он был отлит из оловянистой бронзы [Недашковский, 2010, с. 147-149, 151, № 162]. Аналогичные изделия были широко распространены на памятниках золотоордынского времени от Средней Вятки до Северного Кавказа и от Поднепровья до Западного Казахстана [Недашковский, 2000, с. 49, 51, рис. 9,4; Недашковский, Ракушин, 1998, с. 87, 107 , рис. 3,3; Полякова, 1996, с. 232-233, рис. 74,3; Руденко, 2004, с. 116-117, 137, 149150,155 , рис. $2,1,1 a, 2,12-13,14,15,10$, фото 2 ; Федоров-Давыдов, 1966, с. 82, 116].

Тип 6 (1 экз.). Зеркало имело выпуклую окружность в центре, остальное поле было заполнено ячеистым орнаментом (рис. 2,4). Изделие, согласно данным спектрального анализа, было отлито из оловянистой бронзы [Heдашковский, 2010, с. 147-150, № 152]. Близкие аналогии этому типу были найдены в Среднем и Нижнем Поволжье [Недашковский, 2000 , с. 49,53 , рис. 9,8 ; Полякова, 1996 , с. $227-$ 228 , рис. 71,9], в Калмыкии и Средней Азии [Байпаков, 1990, с. 144, рис. 1].

Отдел Г. Зеркала с низким валикообразным бортиком (рис. 2,5-12).

Тип 11 (2 экз.). Зеркала диаметром около 6,1 см с орнаментом в виде концентрической окружности (рис. 2,5-0). Изделия отлиты из оловянистой бронзы [Недашковский, 2010, с. 147150, №/№ 160-161]. Аналогии известны на Нижнем Дону, в Среднем и Нижнем Поволжье [Каталог.., 1979, с. 72, № 200-2, рис. 30,16; Недашковский, Ракушин, 1998, с. 90, 106, рис. 2,1; Руденко, 2004, с. 113, 146, рис. 11,1,5].
Тип 12 (2 экз.). Без дополнительной орнаментации (помимо невысокого бортика); не исключается наличие у таких зеркал (рис. 2,78 ) боковой подтрапециевидной ручки-петельки. Диаметры изделий около 6 см; согласно данным спектрального анализа они были отлиты из оловянистой бронзы [Недашковский, 2010, с. 147-150, № 156-157]. Известны аналогии таким зеркалам из Нижнего и Среднего Поволжья, а также из бассейна Средней Вятки [Казаков, 1991, с. 90-91, рис. 33,39; Недашковский, Ракушин, 1998, с. 90-91, 106, рис. 2,2,4; Полякова, 1996, с. 216, 223, 237, рис. 69,14 ; Руденко, 2004, с. $113,136,143$, рис. 1,1-5, 8,2-11; Федоров-Давыдов, 1966, c. 78,264 , рис. 13 , АIII, № 326].

Тип 14 (1 экз.). С орнаментацией в виде нескольких расположенных одна в другой арок диаметром 6,6 см (рис. 2,9). Изделие отлито из оловянистой бронзы [Недашковский, 2010, c. 147-150, № 154]. Аналогичные зеркала известны с Болгарского, Царевского и Увекского городищ, селищ Семеновские, IV Старокуйбышевское и Чакма, а также из бассейна Дона и из Кировской области [Казаков, 1991, с. 90-91, рис. 33,30; Каталог..., 1979, табл. 30,2; Недашковский, Ракушин, 1998, с. 91; Полякова, 1996, с. 216, 224, рис. 69,22; Руденко, 2004, с. $115-116,137,141,144,155$, рис. $2,14-15,6$, 9,5-15, фото 1].

Тип 16 (1 экз.). Крестовидный орнамент разделял поле изделия (диаметр 6,9 см) на сектора, в каждом из которых имелось идентичное изображение - сильно стилизованный распускающийся цветок (рис. 2,11). Согласно данным спектрального анализа изделие было отлито из оловянистой бронзы [Недашковский, 2010, с. 147-150, № 158]. Имеются аналогии в кочевнических древностях второй половины XIII - XIV в., в материалах Царевского и Болгарского городищ [Недашковский, Ракушин, 1998, с. 91-92, 106, рис. 2,7; Полякова, 1996, с. 228-229, рис. 72,2; Федоров-Давыдов, 1966, с. 80-81, 116, рис. 14,1,ИI].

Тип 20 (1 экз.). С довольно схематичным изображением двух плывущих друг за другом рыб (рис. 2,10); изделие было отлито из оловянистой бронзы [Недашковский, 2010, с. 147150, № 159]. Зеркала с изображением двух рыб были распространены в золотоордынское время на территории Евразии от Поволжья и 
Северного Кавказа до Приморья. Очень схематичные изображения двух рыб, сходные с данными, имеются на зеркалах из Болгара, с золотоордынского городища Шехрлик в Хорезме, из устья р. Черемшан, из кургана 13 у г. Аткарска и из кургана 2 группы № 3 у с. Советское Саратовской области [Недашковский, Ракушин, 1998, с. 93, 107, рис. 3,6,9; Полякова, 1996, с. 228-229, рис. 72,5; Руденко, 2004, c. 118 , рис. $3,4-5,18,2]$.

Тип еще одного изделия с неясной орнаментацией определить не представляется возможным (рис. 2,12); оно имело диаметр 8,5 см и было отлито из оловянистой бронзы [Недашковский, 2010, с. 147-150, № 153].

Отдел Д. Без выраженного бортика (рис. 2,13).

Тип 2 (1 экз.). Без четких следов орнамента (рис. 2,13), диаметром около 7,5 cм. Согласно данным спектрального анализа изделие было отлито из оловянистой бронзы [Недашковский, 2010, с. 147-150, № 155]. Подобное изделие происходит из кочевнического могильника Зауморье [Недашковский, Ракушин, 1998, с. 94, 105, рис. 1,1].

Булава. Фрагмент бронзового навершия булавы (вес целого предмета, очевидно, достигал 200 г) в виде куба $3,4 \times 3,4$ см со срезанными углами (рис. 2,14) по форме аналогичен многочисленным древнерусским железным булавам XII-XIII вв.; такие изделия встречались также в Волжской Булгарии и Прибалтике [Измайлов, 1997, с. 97-99, 208, рис. $65, I I, 66,4$; Кирпичников, 1966, с. 47-48, 54 , рис. $10, I I, 39,3$, табл. XXV,3].

\section{Конское снаряжение.}

Половина двусоставных кольчатых $y \partial и л$ без псалиев с неподвижными кольцами в форме коротких цилиндров (подъемный материал 2002 г.) имеет общую длину 14,2 см и диаметр кольца 5,4 см. Такие удила характерны для восточноевропейских кочевников золотоордынского времени [Федоров-Давыдов, 1966 , с. $17-18,116$, рис. $2,1, Г I V]$.

Подпружные пряжки (подъемный материал 2002 г.) представлены железными пряжками - круглой диаметром 3,2 см с сохранившимся язычком и подпрямоугольной размерами 4,4 × 4,9 см.

Два кольиа от сбруи (подъемный материал 2002 г.) имеют диаметры 2,9 и 3,4 cм.
Грузик-пломба (рис. 2,24). Можно полагать, что грузики-пломбы служили для пломбирования тюков с товарами или связок шкур, так как в отдельных случаях внутри сплющенной втулки аналогичных изделий встречаются обрывки проволочек или ниток. Предмет конусовидной формы с неясными остатками орнамента, был отлит из сплава олова со свинцом [Hедашковский, 2010, с. 147, 149, 151, № 170].

\section{Предметы быта.}

Заклепки металлических сосудов представлены двумя экземплярами: изготовленным путем сворачивания листа в конус (рис. 2,15 ) и заготовкой подобного изделия (рис. 2,16). Готовая заклепка сплющена и деформирована, что говорит об ее использовании. Предметы были изготовлены из «чистой» меди [Недашковский, 2010, с. 147-149, 151, № 165-166]. Заклепки таких форм, по мнению К.А. Руденко, применялись для крепления ушек тазов; они хорошо известны в памятниках Среднего и Нижнего Поволжья [Недашковский, 2000, с. 81-82, рис. 19,1-9].

Ушко от сосуда (рис. 2,17), вероятно, крепилось к котелку. Согласно данным спектрального анализа изделие было отковано из «чистой» меди [Недашковский, 2010, с. 147149, 151, № 167].

Фрагменты кованых сосудов представлены венчиками (рис. $2,23,25$ ) и стенкой с сохранившейся заклепкой (рис. 2,19). Обломок листа (рис. 2,18), вероятно, также принадлежит к числу фрагментов сосудов. Предметы были изготовлены из оловянистой (2 экз.), свинцово-оловянистой бронзы и «чистой» меди [Недашковский, 2002, с. 335, 337-338, 345, № 135, 137; 2010, c. 147-151, № 2, 164].

Были найдены четыре фрагмента чугунHblx котлов (рис. 3,1); не приведенные на рисунках изделия происходят из подъемного материала 2002 года. Аналогичные котлы представлены на памятниках Золотой Орды и сопредельных территорий [Недашковский, 2000, c. 84-86, рис. 20,2-5]. На расположенном вблизи Хмелевском I селище найдено 6 фрагментов котлов [Недашковский, Шигапов, 2016а, с. 656].

Железная ручка ведра (рис. 4,1) имеет длину 38,2 см и высоту 20,5 см.

Имеется железный серп (рис. 3,3); длина сохранившейся части $18 \mathrm{~cm}$, ширина лезвия - до 3,2 см. 
Железные замки (5 экз.) относятся к типу В (по классификации Б.А. Колчина); помимо изображенного на рисунке изделия (рис. 3,4 ) три небольших фрагментарно сохранившихся замка происходят из подъемного материала 2002 г., а один - из культурного слоя раскопа I-2002 (№ 3, -34 см). Такие замки состояли из скрепленных между собой двух цилиндров и запирающей дужки. Данный тип замков был широко распространен в Древней Руси с середины XII по начало XV в., а также на поселениях Среднего и Нижнего Поволжья, в Азаке и в Старом Орхее [Казаков, 1991, с. 74; Кокорина, Фахрутдинов, 2011 , с. 213 , рис. 33,10 ; Недашковский, 2000, с. 87-89, рис. 21,1-10; Руденко, 2011, с. 132, рис. 13,1-2,7; Савченкова, 1996, с. 40-43, рис. $14,1-8,10,15,17]$.

Пуговииа литая, круглая, с орнаментом в виде насечек (рис. 2,20).

Бубенчик представлен фрагментом двусоставного экземпляра, у которого сохранилось ушко (рис. 2,21). Бубенчики могли использоваться как украшения одежды. Согласно данным спектрального анализа изделие было отлито из многокомпонентного сплава с преобладанием цинка над оловом [Недашковский, 2010, с. 147, 149,151, № 168]. Подобные изделия известны в материалах Восточной Европы, Средней Азии и Сибири IX-XIV вв. [Недашковский, 2001, с. 349-350, 360, рис. 1,4-6; Полякова, 1996, с. 196, 200-202, рис. 65,28-29,32-34; Федоров-Давыдов, Вайнер, Гусева, 1974, с. 117, табл. IV,18; Nedashkovsky, 2004, p. 45-46, 224, fig. 58,4-6].

Муфта ножа была вырезана из металлического листа (рис. 2,22). Предмет изготовлен из свинцово-оловянистой бронзы [Недашковский, 2010, с. 147, 149, 151, № 169]. Аналогичные изделия известны с поселений Нижнего Поволжья золотоордынского времени, в том числе с Увекского городища [Недашковский, 2001, с. 353, 361, pис. 2,1-26; Nedashkovsky, 2004, p. 47, 225, fig. 59,1-26], Среднего Поволжья, Хорезма, из курганов золотоордынских кочевников и из раскопок Белоозера [Захаров, 2004, с. 194 , табл. 192 , рис. $119,1-7]$.

Фрагмент костяной рукояти ножа (рис. 2,27). Изделие украшено орнаментом из желобчатых кольцевых линий.

Бараний астрагал с отверстием (рис. 2,26), залитым сплавом свинца с оловом [Недашковский, 2010, с. 147, 149, 151, № 171], сохранился фрагментарно. Известно, что астрагалы, в том числе их свинцовые отливки, являются нередкой находкой в золотоордынских городах - они использовались для игры в бабки [Федоров-Давыдов, 2001, с. 228].

Имеется фрагмент бесформенного слитка (раскоп I-2001, яма 1, № 6, -148 см) «чистой» меди [Недашковский, 2002, с. 335, 338, 345, № 136].

Ножи представлены тремя фрагментированными экземплярами с прямой спинкой и длиной лезвия не менее 6-7,7 см (подъемный материал 2002 г.).

Шило имеет длину $6,6 \mathrm{~cm}$, а 4 гвоздя 4,5-11,8 см (шурф 1996 г.; раскоп I-2002, культурный слой, № 5, -9 см, № 6, -55 см; подъемный материал 2002 г.).

С памятника происходят также 8 неопределенных железных предметов (рис. 3,2,5, $4,2)$; не приведенные на рисунке изделия имеют длину 4,8-10,4 см (раскоп I-2002, культурный слой, № $1,-40$ см, № $8,-43$ см, яма 1, № 11, -153 см, № 12, -138 см; подъемный материал 2002 г.).

Золотоордынская неполивная гончарная керамика (рис. 4,5, 5,11-13, табл. 1-2) присутствует лощеная $(18,1 \%$ ) (рис. 5,12$)$ и нелощеная $(81,9 \%$ ) (рис. $4,5,5,11,13)$; керамика хорошего (рис. 5,11-13) обжига (69,5\%) заметно преобладает над плохо обожженной (рис. 4,5) керамикой $(30,5 \%$ ). Коричневой посуды (рис. 4,5, $5,12-13)$ 72,4 \%, красной (рис. 5,11) - 23,9\%, бурой $-2,2 \%$, желтой $-0,8 \%$, серой $-0,7 \%$.

Имеется горло одноручного кувшина с диаметром венчика 10,2 см (рис. 4,5).

Золотоордынская керамика имеет примесь мелкого песка в тесте, иногда посуда дополнена красным ангобом. Керамика украшена орнаментом в виде прочерченных горизонтальных линий (рис. 5,11-13), многорядной (рис. 5,13) и однорядной (рис. 5,12) волны, оттисков гребенчатого штампа, фестонов (рис. 5,12 ) и оттисков палочки; есть сосуды, покрытые вертикальным лощением.

Имеется керамическое напрясло (рис. 5,1) из стенки коричневого неполивного золотоордынского нелощеного хорошо обожженного сосуда с примесью песка в тесте.

Фрагменты древнерусской керамики (рис. 5,2-10) имеют примесь в тесте дресвы и песка (рис. 5,2,5-7,10), а также только пес- 
ка (рис. 5,3-4, 8-9); цвет посуды коричневый (рис. 5,2-3,5-8,10) или серый (рис. 5,4,9). На некоторых изделиях нанесен орнамент в виде горизонтальных линий (рис. 5,2,9). Древнерусская керамика из слоя раскопа I представлена 68 фрагментами, в ямах найдено 93 фрагмента (табл. 1, 3). Находки древнерусской керамики на раскопе I составляют $16,4 \%$ от всей керамической посуды.

Фрагменты мордовской посуды (табл. 1, 3) имеют в тесте примесь шамота. Мордовская лепная керамика из слоя раскопа I представлена 31 фрагментом, из ям - 34 фрагментами; находки такой посуды составляют 6,6 \% от всей найденной керамики.

Из общей массы неполивной керамической посуды выделяются трапезундские амфоры (рис. 4,3-4), их найдено при раскопках на селище 11 фрагментов. Из них 5 обнаружено в яме 1 , а 6 - в слое. Один из фрагментов амфоры происходит из подъемного материала. Трапезундские амфоры имеют краснооранжевый цвет, с мелким рифлением и белым ангобом, а также примесь в тесте мелкого песка и слюды.

В составе подъемного материала встречена кашинная керамика с бирюзовой поливой и полихромной росписью, а также фрагмент красноглиняного поливного сосуда с бирюзовой поливой. На раскопе I в 2002 г. в слое найден фрагмент кашинной керамики с рельефом и полихромной росписью, а в 2001 г. в яме 1 найден фрагмент поливной красноглиняной посуды древнерусского облика с примесью дресвы и песка в тесте и темно-зеленой глазурью.

При раскопках найдено значительное количество глиняной обмазки (включая 7 фрагментов обмазки тандыра), камней и костей животных, кирпичи, железные и керамические шлаки, 4 фрагмента керамики эпохи бронзы и кварцитовый отщеп (табл. 3).

Представленная коллекция предметов золотоордынского времени, происходящая с сельского поселения Широкий Буерак, позволяет сделать некоторые выводы. Сравним приведенные материалы с изделиями тех же категорий, происходящими с Увекского городища [Недашковский, 2000, с. 67-
93, 106-107, 109; 2001], на месте которого располагался близлежащий крупный город Укек, и Хмелевского I селища [Недашковский, Шигапов, 2015; 2016а; 2016б], близлежащего малого города. Обращает на себя внимание наличие всего одного украшения (поясная накладка) и всего одного предмета вооружения (булава) на селище Широкий Буерак, что резко отличает материальную культуру этого сельского поселения. Примечательно незначительное количество красноглиняной поливной и кашинной керамики, найденной на селище. В то же время на селище присутствует медная и чугунная посуда (хотя и в меньшем количестве, чем на Увекском городище и Хмелевском I селище), а также импортная амфорная тара. Эти факты свидетельствуют о существовании развитых торговых связей между поселением Широкий Буерак и близлежащими городами.

Сравним распространение различных групп зеркал на селище Широкий Буерак с материалами Увекского городища, Хмелевского I селища и кочевнических курганов [Недашковский, 2000, с. 65-66, табл. 3]. По количеству экземпляров зеркал с узким высоким бортиком, в процентах от всей коллекции, данные по Широкому Буераку (25 \%), сельскому поселению, ближе к курганам кочевников $(25,6 \%)$, чем к близлежащим городам. Количество изделий с низким валикообразным бортиком и без выраженного бортика, найденных на селище Широкий Буерак $(74,4$ \%), также ближе к аналогичным данным по подкурганным захоронениям (64,1 \%). Таким образом, судя по распространенности зеркал разных типов, отражающей вкусы местного населения, селище Широкий Буерак ближе к комплексам номадов, чем горожан.

Доля древнерусской и мордовской керамики на селище Широкий Буерак существенно больше (в 4,4 раза для древнерусской и в 16,5 раз для мордовской), чем на Хмелевском I поселении. Эти данные, подкрепленные находками костей свиньи в кухонных остатках с Широкого Буерака, позволяют говорить о значительных отличиях в этническом составе населения этих памятников. 


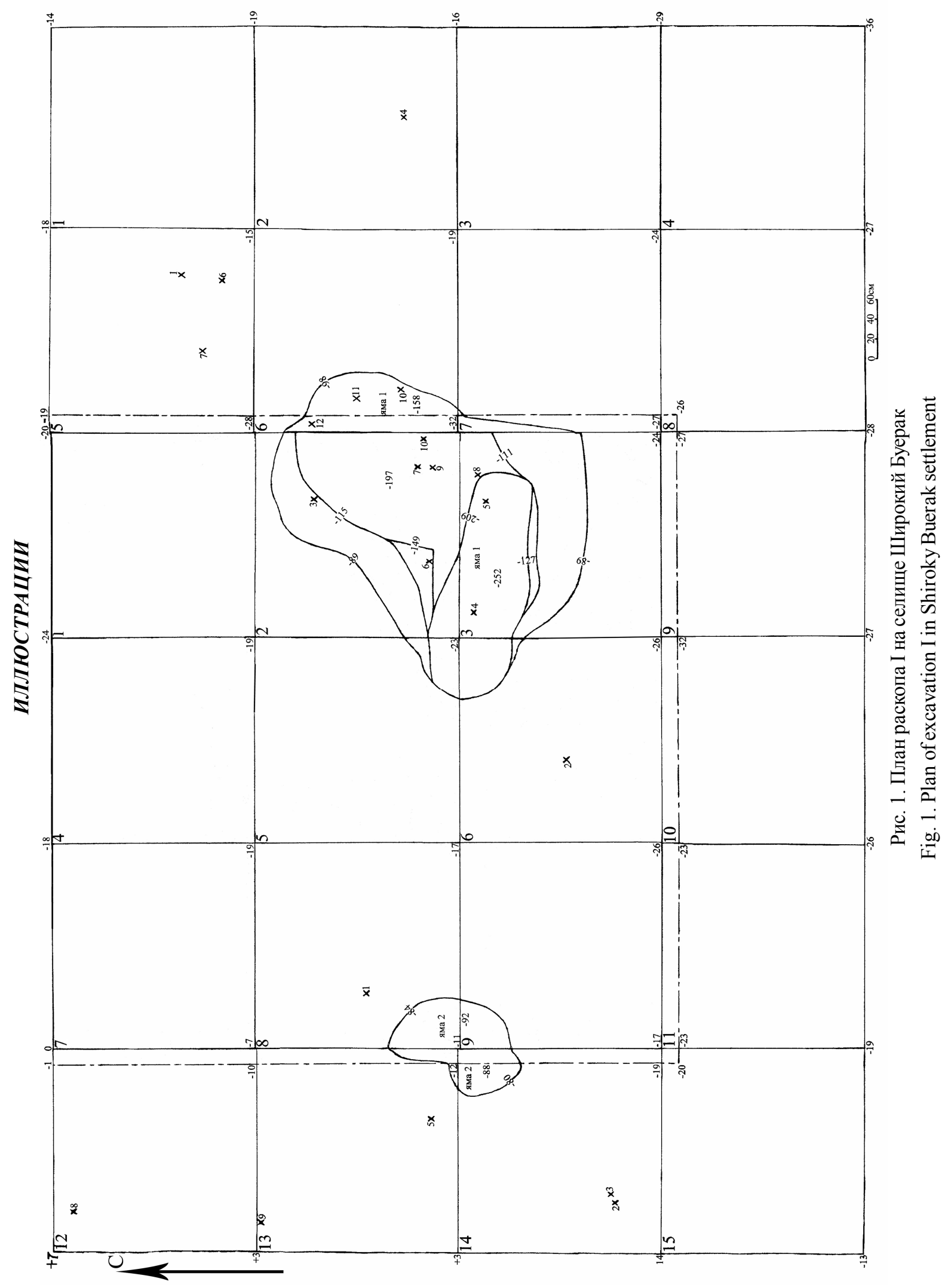




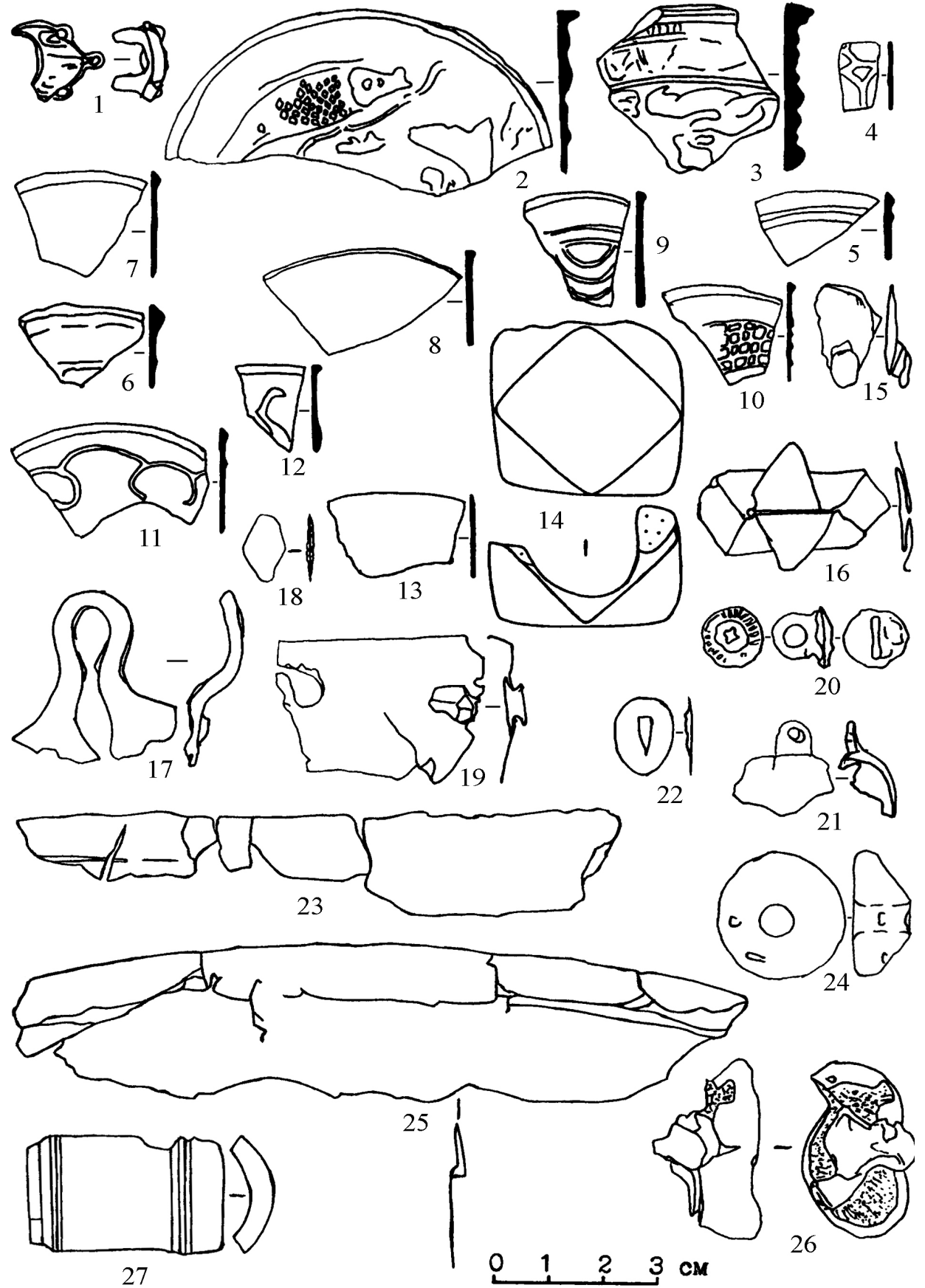

Рис. 2. Накладка (1), фрагменты зеркал (2-13), булавы (14), заклепки (15-16), ушко (17), обломок листа (18), фрагменты кованых сосудов $(19,23,25)$, пуговица (20), бубенчик (21), муфта (22) и фрагмент рукояти (27) ножа, грузик-пломба (24), бараний астрагал с отверстием, залитым свинцом (26), с селища Широкий Буерак. Саратовский областной музей краеведения:

1-23, 25 - бронза; 24 - свинец; 26 - кость и свинец; 27 - кость. 1-17, 19-22, 24, 26 - подъемный материал Л.Ф. Недашковского 2002 г. $(1-13,15-17,19-22,24,26)$ и 1996 г. (14). 18, 27 - раскоп I-2002: 18 - культурный слой (№ 7, -62 см); 27 - яма 1 (№ 10, -127 см); 23, 25 - раскоп I-2001, яма 1 (№ 8, -163 см; № 5, -131 см)

Fig. 2. Bracket (1), fragments of mirrors (2-13), mace-head (14), rivets (15-16), handle (17), fragment of sheet (18), fragments of forged vessels (19, 23, 25), button (20), little bell (21), coupling (22) and fragment of handle (27) of knifes, weight-seal (24), ram's knucklebone with aperture, poured with lead (26), from the Shiroky Buerak settlement. Saratov regional museum of regional ethnography:

1-23, 25 - bronze; 24 - lead; 26 - bone and lead; 27 - bone. 1-17, 19-22, 24, 26 - investigations of L.F. Nedashkovsky of $2002(1-13,15-17,19-22,24,26)$ and $1996(14) .18,27$ - trench I-2002: 18 - cultural layer (no. 7, -62 cm); 27 - pit 1 (no. $10,-127 \mathrm{~cm}$ ); 23, 25 - trench I-2001, pit 1 (no. $8,-163 \mathrm{~cm} ;$ no. $5,-131 \mathrm{~cm}$ ) 

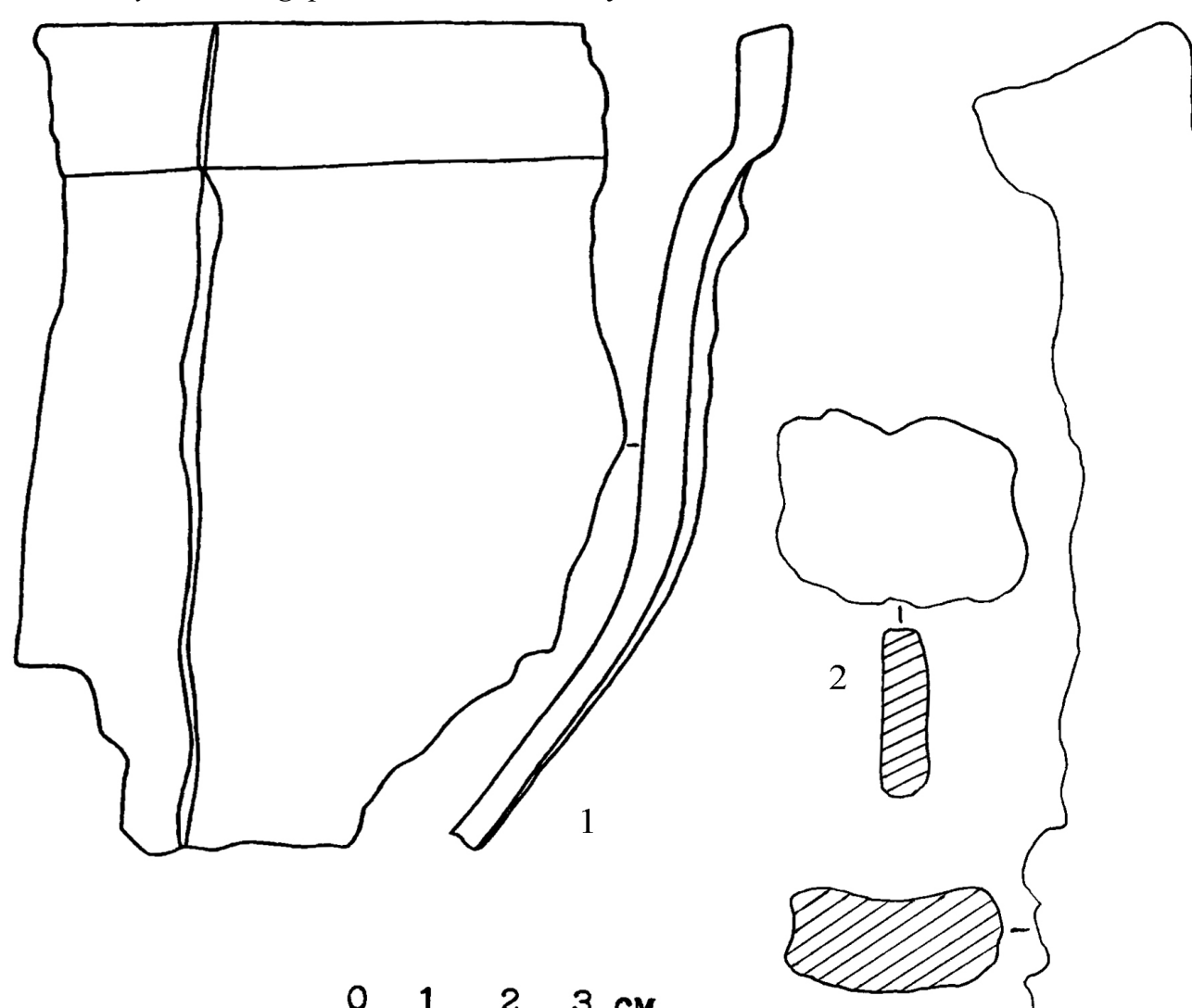


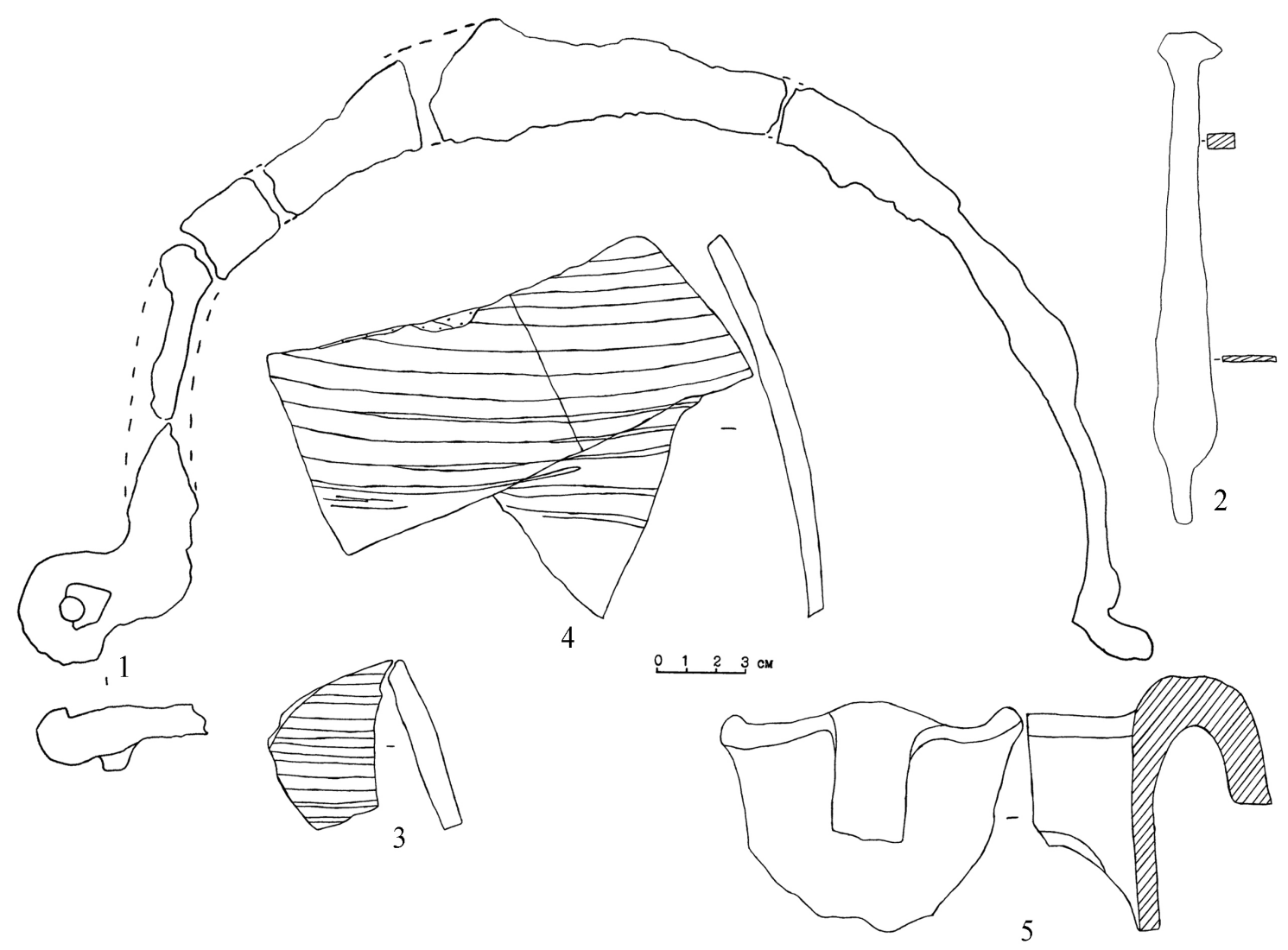

Рис. 4. Железные ручка ведра (1) и неопределенный предмет (2), фрагменты трапезундских амфор (3-4), золотоордынского неполивного кувшина (5) из раскопа I-2001 с селища Широкий Буерак.

Саратовский областной музей краеведения:

1, 3-5 - яма 1 (1 - № 9, -167 см); 2 - культурный слой (№ 1, -42 см)

Fig. 4. Iron bucket handle (1) and uncertain object (2), fragments of Trebizond amhorae (3-4), Golden Horde unglazed jar (5) from trench I-2001 at the Shiroky Buerak settlement.

Saratov regional museum of regional ethnography:

$1,3-5$ - pit $1(1-$ no. $9,-167 \mathrm{~cm}) ; 2$ - cultural layer (no. $1,-42 \mathrm{~cm})$ 

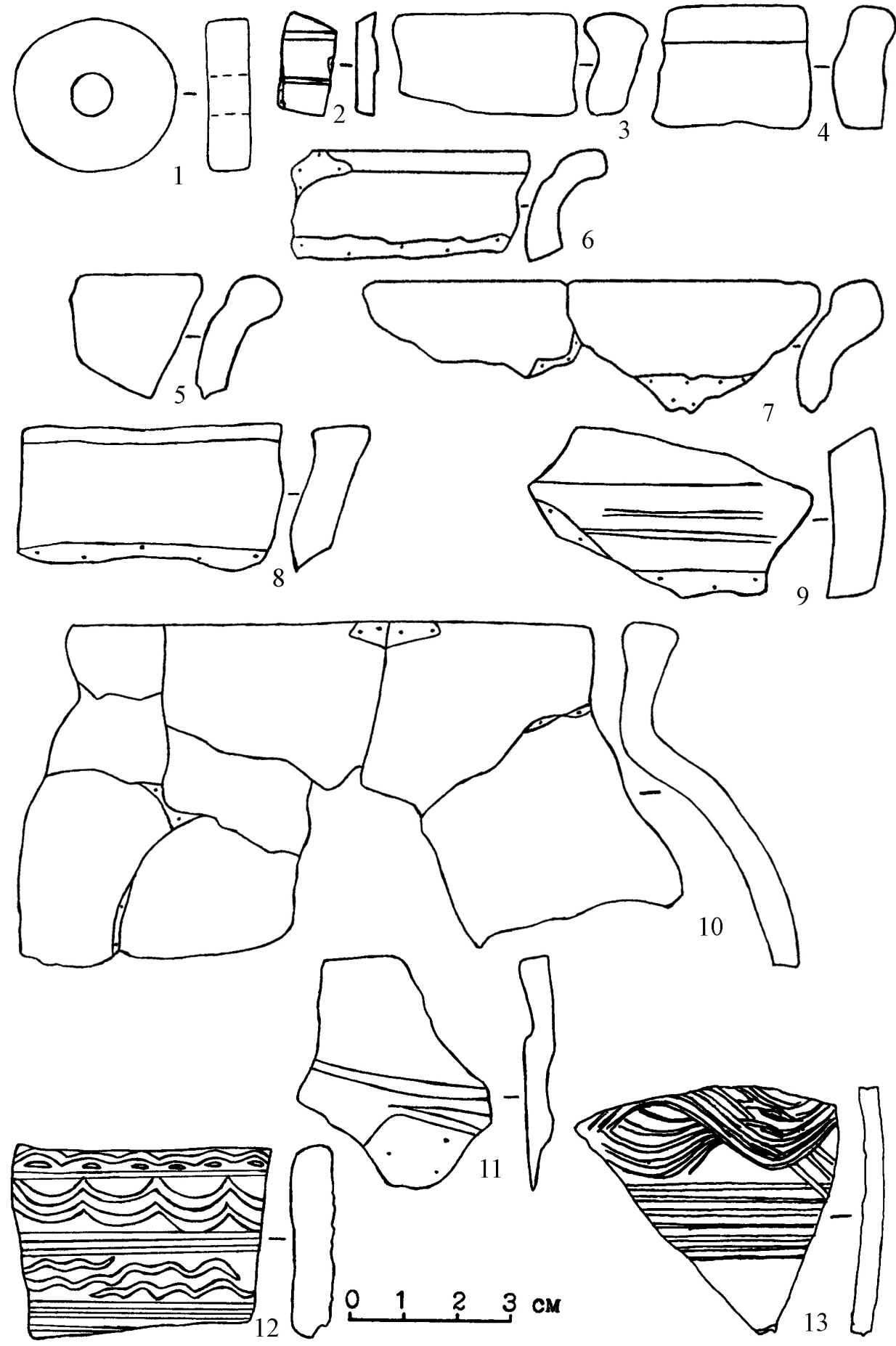

Рис. 5. Керамическое напрясло из стенки сосуда (1), фрагменты древнерусской (2-10) и золотоордынской неполивной (11-13) керамики с селища Широкий Буерак. Саратовский областной музей краеведения:

1 - раскоп I-2002, культурный слой (№ 9, -64 см). 2, 5, 7, 12-13 - подъемный материал Л.Ф. Недашковского 2002 (2, 13) и 1996 гг. $(5,7,12) .3-4,8-11$ - раскоп I-2001: 3, 8, 10 - яма 1; 4, 9 - яма 2; 11 - культурный слой. 6 - шурф 1996 г., культурный слой

Fig. 5. Ceramic spindle whorl made from a wall of a vessel (1), fragments of Old Russian (2-10) and Golden Horde unglazed (11-13) pottery from the Shiroky Buerak settlement.

Saratov regional museum of regional ethnography:

1 - trench I-2002, cultural layer (no. 9, -64 cm). 2, 5, 7, 12-13 - investigations of L.F. Nedashkovsky of 2002 $(2,13)$ and $1996(5,7,12) .3-4,8-11$ - trench I-2001:3, 8, 10 - pit $1 ; 4,9$ - pit $2 ; 11$ - cultural layer. 6 - probe trench of 1996 , cultural layer 
Количественное распределение фрагментов неполивной золотоордынской, древнерусской и мордовской лепной керамики из раскопа I на селище Широкий Буерак

\begin{tabular}{|l|c|c|c|}
\hline Штык, яма & Золотоордынская & Древнерусская & Мордовская \\
\hline Штык 1 & 185 & 22 & 2 \\
\hline Штык 2 & 172 & 30 & 21 \\
\hline Штык 3 & 77 & 14 & 7 \\
\hline Бровка & 18 & 2 & 1 \\
\hline Всего из слоя & $\mathbf{4 5 2}$ & $\mathbf{6 8}$ & $\mathbf{3 1}$ \\
\hline Яма 1 & 286 & 91 & 33 \\
\hline Яма 2 & 2 & 2 & 1 \\
\hline Всего из ям & $\mathbf{2 8 8}$ & $\mathbf{9 3}$ & $\mathbf{3 4}$ \\
\hline Итого & $\mathbf{7 4 0}$ & $\mathbf{1 6 1}$ & $\mathbf{6 5}$ \\
\hline
\end{tabular}

Таблийа 2

Статистика неполивной золотоордынской гончарной керамики из раскопа I на селище Широкий Буерак

\begin{tabular}{|c|c|c|c|c|c|c|c|c|c|c|c|c|c|c|c|c|c|c|c|c|c|}
\hline \multirow{3}{*}{ Штык, яма } & \multicolumn{4}{|c|}{ Красная } & \multicolumn{4}{|c|}{ Коричневая } & \multicolumn{4}{|c|}{ Бурая } & \multicolumn{4}{|c|}{ Желтая } & \multicolumn{4}{|c|}{ Серая } & \multirow{3}{*}{ Всего } \\
\hline & \multicolumn{2}{|c|}{ лощ } & \multicolumn{2}{|c|}{ н/лощ } & \multicolumn{2}{|c|}{ лощ } & \multicolumn{2}{|c|}{ н/лощ } & \multicolumn{2}{|c|}{ лощ } & \multicolumn{2}{|c|}{ н/лощ } & \multicolumn{2}{|c|}{ лощ } & \multicolumn{2}{|c|}{ н/лощ } & \multicolumn{2}{|c|}{ лощ } & \multicolumn{2}{|c|}{ н/лощ } & \\
\hline & $\mathrm{x} / \mathrm{o}$ & $\Pi / \mathrm{o}$ & $\mathrm{x} / \mathrm{o}$ & $\Pi / \mathrm{o}$ & $\mathrm{x} / \mathrm{o}$ & $\Pi / \mathrm{o}$ & $\mathrm{x} / \mathrm{o}$ & $\Pi / \mathrm{o}$ & $\mathrm{x} / \mathrm{o}$ & $\Pi / \mathrm{o}$ & $\mathrm{x} / \mathrm{o}$ & п/о & $\mathrm{x} / \mathrm{o}$ & $\Pi / \mathrm{o}$ & $\mathrm{x} / \mathrm{O}$ & $\Pi / \mathrm{o}$ & $\mathrm{x} / \mathrm{o}$ & $\Pi / \mathrm{o}$ & $\mathrm{x} / \mathrm{o}$ & $\Pi / \mathrm{o}$ & \\
\hline Штык 1 & 5 & 2 & 28 & 10 & 12 & 4 & 80 & 37 & - & - & 2 & 2 & - & - & 1 & - & - & - & - & 2 & 185 \\
\hline Штык 2 & 24 & - & 35 & 5 & 17 & 3 & 53 & 21 & 1 & - & 5 & 3 & 1 & - & 3 & - & - & 1 & - & - & 172 \\
\hline Штык 3 & 4 & 1 & 10 & 5 & 8 & 4 & 29 & 11 & - & - & - & 2 & - & - & 1 & - & - & - & - & 2 & 77 \\
\hline Бровка & - & - & 2 & 1 & 4 & - & 9 & 2 & - & - & - & - & - & - & - & - & - & - & - & - & 18 \\
\hline Всего и & 33 & 3 & 75 & 21 & 41 & 11 & 171 & 71 & 1 & - & 7 & 7 & 1 & - & 5 & - & - & 1 & - & 4 & 452 \\
\hline Яма 1 & 6 & 4 & 19 & 16 & 27 & 6 & 127 & 80 & - & - & - & 1 & - & - & - & - & - & - & - & - & 286 \\
\hline Яма 2 & - & - & - & - & - & - & 1 & 1 & - & - & - & - & - & - & - & - & - & - & - & - & 2 \\
\hline Всего из ям & 6 & 4 & 19 & 16 & 27 & 6 & 128 & 81 & - & - & - & 1 & - & - & - & - & - & - & - & - & 288 \\
\hline Итого & 39 & 7 & \begin{tabular}{|l|}
94 \\
\end{tabular} & 37 & 68 & 17 & 299 & 152 & 1 & - & 7 & 8 & 1 & - & 5 & - & - & 1 & - & 4 & 740 \\
\hline
\end{tabular}

Статистика находок из раскопа I на селище Широкий Буерак

Таблица 3 (без золотоордынской неполивной гончарной керамики и индивидуальных находок)

\begin{tabular}{|l|c|c|c|c|c|c|c|c|c|c|c|c|c|c|}
\hline $\begin{array}{c}\text { Штык, } \\
\text { яма }\end{array}$ & $\begin{array}{c}\text { Ка- } \\
\text { шинная } \\
\text { кера- } \\
\text { мика }\end{array}$ & $\begin{array}{c}\text { Крас- } \\
\text { няглая } \\
\text { полив- } \\
\text { ная ке- } \\
\text { рамика }\end{array}$ & $\begin{array}{c}\text { Мовская } \\
\text { лепная } \\
\text { кера- } \\
\text { мика }\end{array}$ & $\begin{array}{c}\text { Древ- } \\
\text { нерус- } \\
\text { ская } \\
\text { кера- } \\
\text { мика }\end{array}$ & $\begin{array}{c}\text { Кера- } \\
\text { миче- } \\
\text { ский } \\
\text { шлак }\end{array}$ & $\begin{array}{c}\text { Фраг- } \\
\text { менты } \\
\text { трапе- } \\
\text { зунд- } \\
\text { ских } \\
\text { амфор }\end{array}$ & $\begin{array}{c}\text { Кости } \\
\text { Камни }\end{array}$ & $\begin{array}{c}\text { Фраг- } \\
\text { менты } \\
\text { глиня- } \\
\text { ной } \\
\text { обмаз- } \\
\text { ки }\end{array}$ & $\begin{array}{c}\text { менаг- } \\
\text { обмаз- } \\
\text { ки тан- } \\
\text { дыра }\end{array}$ & $\begin{array}{c}\text { Кирпичез- } \\
\text { ный } \\
\text { шлак }\end{array}$ & $\begin{array}{c}\text { Кера- } \\
\text { мика } \\
\text { эпохи } \\
\text { бронзы }\end{array}$ & $\begin{array}{c}\text { Квар- } \\
\text { цито- } \\
\text { вый } \\
\text { отщеп }\end{array}$ \\
\hline Штык 1 & - & - & 2 & 22 & - & 4 & 76 & 142 & 2 & 2 & 13 & 3 & - & - \\
\hline Штык 2 & 1 & 1 & 21 & 30 & - & 1 & 313 & 191 & 3 & 1 & 4 & 1 & - & - \\
\hline Штык 3 & - & - & 7 & 14 & - & 1 & 188 & 27 & 7 & 4 & - & 1 & 3 & - \\
\hline Бровка & - & - & 1 & 2 & - & - & 28 & 2 & 3 & - & - & - & - & - \\
\hline $\begin{array}{l}\text { Всего } \\
\text { из слоя }\end{array}$ & $\mathbf{1}$ & $\mathbf{1}$ & $\mathbf{3 1}$ & $\mathbf{6 8}$ & - & $\mathbf{6}$ & $\mathbf{6 0 5}$ & $\mathbf{3 6 2}$ & $\mathbf{1 5}$ & $\mathbf{7}$ & $\mathbf{1 7}$ & $\mathbf{5}$ & $\mathbf{3}$ & - \\
\hline Яма 1 & - & 1 & 33 & 91 & 5 & 5 & 834 & 89 & 55 & - & 6 & 16 & 1 & 1 \\
\hline Яма 2 & - & - & 1 & 2 & - & - & 3 & 1 & 5 & - & - & - & - & - \\
\hline $\begin{array}{l}\text { Всего } \\
\text { из ям }\end{array}$ & - & $\mathbf{1}$ & $\mathbf{3 4}$ & $\mathbf{9 3}$ & $\mathbf{5}$ & $\mathbf{5}$ & $\mathbf{8 3 7}$ & $\mathbf{9 0}$ & $\mathbf{6 0}$ & - & $\mathbf{6}$ & $\mathbf{1 6}$ & $\mathbf{1}$ & $\mathbf{1}$ \\
\hline Итого & $\mathbf{1}$ & $\mathbf{2}$ & $\mathbf{6 5}$ & $\mathbf{1 6 1}$ & $\mathbf{5}$ & $\mathbf{1 1}$ & $\mathbf{1 4 4 2}$ & $\mathbf{4 5 2}$ & $\mathbf{7 5}$ & $\mathbf{7}$ & $\mathbf{2 3}$ & $\mathbf{2 1}$ & $\mathbf{4}$ & $\mathbf{1}$ \\
\hline
\end{tabular}




\section{СПИСОК ЛИТЕРАТУРЫ}

Акишев К. А., Байпаков К. М., Ерзакович Л. Б., 1987. Отрар в XIII-XV веках. Алма-Ата : Наука КазССР. 353 c.

Байпаков К. М., 1990. По следам древних городов Казахстана (Отрарский оазис). Алма-Ата : Наука КазССР. 205 с.

Железчиков Б. Ф., Кутуков Д. В., 1998. Раскопки у села Маляевка // Древности Волго-Донских степей : сб. науч. ст. Вып. 6. Волгоград : Изд-во ВолГУ. С. 124-140.

Захаров С. Д., 2004. Древнерусский город Белоозеро. М. : Индрик. 592 с.

Измайлов И. Л., 1997. Вооружение и военное дело населения Волжской Булгарии X - начала XIII в. Магадан : СВНЦ ДВО РАН. 212 c.

Казаков Е. П., 1991. Булгарское село Х-ХІІІ вв. низовий Камы. Казань : Татар. кн. изд-во. 176 с.

Каталог археологических коллекций, 1979 / сост. Б. А. Раев. Новочеркасск : Ленуприздат. $161 \mathrm{c.}$

Кирпичников А. Н., 1966. Древнерусское оружие. Вып. 2. Копья, сулицы, боевые топоры, булавы, кистени IX-XIII вв. М. ; Л. : Наука. 147 с.

Кокорина Н. А., Фахрутдинов Р. Г., 2011. Гончарные комплексы Иски-Казани // Татарская археология. № 1-2 (20-21). С. 152-217.

Крамаровский М. Г., 2001. Золото Чингисидов: культурное наследие Золотой Орды. СПб. : Славия. $364 \mathrm{c.}$

Кригер В. А., 1985. Отчет о раскопках в 1985 г. в Среднеахтубинском (п. Рахинка) и Ленинском (Бахтияровка III) районах Волгоградской области // Архив ИА РАН. Р-1. № 10773.

Круглов Е. В., Клепиков В. М., 1993. Средневековые памятники из Фроловского района Волгоградской области // Древности Волго-Донских степей : сб. науч. ст. Вып. 3. Волгоград : Изд-во ВолГУ. С. $138-151$.

Недашковский Л. Ф., 2000. Золотоордынский город Укек и его округа. М. : Восточная литература PAH. $224 \mathrm{c}$.

Недашковский Л. Ф., 2001. Металлические изделия и литейные формы с Увекского городища // Древние ремесленники Приуралья : материалы Всерос. науч. конф. (г. Ижевск, $21-$ 23 нояб. 2000 г.). Ижевск : УИИЯЛ УрО РАН. C. 349-364.

Недашковский Л. Ф., 2002. Химический состав изделий из цветных металлов с золотоордынских поселений центральной части Саратовской области // Нижневолжский археологический вестник. Вып. 5. Волгоград : Изд-во ВолГУ. C. $335-347$.

Недашковский Л. Ф., 2010. Химический состав изделий из цветных металлов с золотоордынс- ких селищ округи Укека // Интеграция археологических и этнографических исследований. Ч. 1. Казань : Изд-во Ин-та истории им. Ш. Марджани АНРТ. С. 147-151.

Недашковский Л. Ф., 2012. Исследования селищ Константиновское, Колотов Буерак и Широкий Буерак // Актуальные вопросы археологии Поволжья. К 65-летию студенческого научного археологического кружка Казанского университета. Казань : ЯЗ. С. 102-108.

Недашковский Л. Ф., Ракушин А. И., 1998. Бронзовые зеркала второй половины X - XIV в. из музеев Саратовской области // Татарская археология. № 2 (3). С. 87-108.

Недашковский Л. Ф., Шигапов М. Б., 2015. Украшения и зеркала с Хмелевского I селища // Ученые записки Казанского университета. Серия «Гуманитарные науки». Т. 157. Кн. 3. С. 34-45.

Недашковский Л. Ф., Шигапов М. Б., 2016а. Изделия из металла с Хмелевского I селища // Ученые записки Казанского университета. Серия «Гуманитарные науки». Т. 158. Кн. 3. С. 653-665.

Недашковский Л. Ф., Шигапов М. Б., 2016б. Находки с Хмелевского I селища // Проблемы Археологии Нижнего Поволжья : материалы V Междунар. Нижневолж. археол. конф., 15-18 нояб. 2016 г. Элиста : Изд-во Калмыц. ун-та. С. 242-247.

Полякова Г. Ф., 1996. Изделия из цветных и драгоценных металлов // Город Болгар: Ремесло металлургов, кузнецов, литейщиков. Казань : Тип. «Татполиграф». С. 154-268.

Руденко К. А., 2004. Металлические зеркала золотоордынского времени из собрания Национального музея Республики Татарстан // Татарская археология. № 1-2 (12-13). С. 111-156.

Руденко К. А., 2011. Города и села Булгарского улуса Золотой Орды (особенности материальной культуры) // Татарская археология. № 1-2 (2021). C. $32-151$.

Савченкова Л. Л., 1996. Черный металл Болгара. Типология // Город Болгар: Ремесло металлургов, кузнецов, литейщиков. Казань : Тип. «Татполиграф». С. 5-88.

Федоров-Давыдов Г. А., 1966. Кочевники Восточной Европы под властью золотоордынских ханов. Археологические памятники. М. : Изд-во Моск. ун-та. $274 \mathrm{c}$.

Федоров-Давыдов Г. А., 2001. Золотоордынские города Поволжья. Керамика. Торговля. Быт. М. : Изд-во Моск. ун-та. 254 с.

Федоров-Давыдов Г. А., Вайнер И. С., Гусева Т. В., 1974. Исследования трех усадеб в восточном пригороде Нового Сарая (Царевского городища) // Города Поволжья в средние века. М. : Наука. С. 89-131. 
Шнайдштейн Е. В., 1979. Раскопки курганов в урочище «Гува» // Археологические памятники Калмыцкой степи. Элиста : Калм. НИИ истории, философии и экономики. C. $55-68$.

Nedashkovsky L. F., 2004. Ukek: The Golden Horde city and its periphery/BAR. International Series, 1222. Oxford: Archaeopress. 253 p.

\section{REFERENCES}

Akishev K.A., Baypakov K.M., Erzakovich L.B., 1987. Otrar in the XIII-XV centuries. Alma-Ata, Nauka Publ. KazSSR. 353 p. (in Russian).

Baypakov K.M., 1990. On traces of ancient cities of Kazakhstan (Otrar oasis). Alma-Ata, Nauka Publ. KazSSR. 205 p. (in Russian).

Zhelezchikov B.F., Kutukov D.V., 1998. Excavations at village Malyayevka. Drevnosti Volgo-Donskikh stepey: sb. nauch. st., iss. 6. Volgograd, Izd-vo VolGU, pp. 124-140. (in Russian).

Zaharov S.D., 2004. Old Russian city Beloozero. Moscow, Indrik Publ. 592 p. (in Russian).

Izmaylov I.L., 1997. Arms and military business of the population of Volga Bulgaria in the $X$ beginning of the XIII century. Magadan, Izdvo SVNC DVO RAN. 212 p. (in Russian).

Kazakov E.P., 1991. Bulgar village of the $X$ XIII centuries in the Low Kama region. Kazan', Tatar. kn. izd-vo. 176 p. (in Russian).

Katalog, 1979. Catalogue of archaeological collections. Compiled by B.A. Raev. Novocherkassk, Lenuprizdat Publ. 161 p. (in Russian).

Kirpichnikov A.N., 1966. Old Russian arms. Iss. 2. Spears, javelins, battle axes, maces, kisten's of IXth-XIIIth centuries. Moscow; Leningrad, Nauka Publ. 147 p. (in Russian).

Kokorina N.A., Fakhrutdinov R.G., 2011. Pottery complexes of Iski-Kazan'. Tatarskaya arkheologiya, no. 1-2 (20-21), pp. 152-217. (in Russian).

Kramarovsky M.G., 2001. Gold of Chingisids: Cultural Heritage of the Golden Horde. St. Petersburg, Slaviya Publ. 364 p. (in Russian).

Kriger V.A., 1985. The report on excavations in 1985 in Sredneakhtubinsky (farm Rakhinka) and Leninsky (Bakhtiyarovka III) areas of the Volgograd region. ArkhivIA RAN, R-1, no. 10773. (in Russian).

Kruglov E.V., Klepikov V.M., 1993. Medieval monuments in Frolovsky district of Volgograd region. Drevnosti Volgo-Donskikh stepey: sb. nauch. st., iss. 3. Volgograd, Izd-vo VolGU, pp. 138-151. (in Russian).
Nedashkovsky L.F., 2000. The Golden Horde city Ukek and its regions. Moscow, Vostochnaya literatura Publ. of RAS. 224 p. (in Russian).

Nedashkovsky L.F., 2001. Metal wares and casting moulds from the Uvek site. Drevnie remeslenniki Priuralia: materialy Vseros. nauch. konf. (g. Izhevsk, 21-23 noiab. 2000 g.). Izhevsk, Izd-vo UIIYaL UrO RAN, pp. 349-364. (in Russian).

Nedashkovsky L.F., 2002. The chemical composition of the non-ferrous articles from the Golden Horde settlements of the central part of Saratov region. The Lower Volga Archaeological Bulletin, iss. 5. Volgograd, Izd-vo VolGU, pp. 335-347. (in Russian).

Nedashkovsky L.F., 2010. The chemical composition of the non-ferrous articles from the Golden Horde settlements of Ukek region. Integration of archaeological and ethnographical researches, part 1. Kazan, Izd-vo In-ta istorii im. Sh. Mardzhani AN RT, pp. 147-151. (in Russian).

Nedashkovsky L.F., 2012. Researches of settlements Konstantinovskoe, Kolotov Buerak and Shiroky Buerak. Aktualnye voprosy arkheologii Povolzhia. K 65-letiiu studencheskogo nauchnogo arkheologicheskogo kruzhka Kazanskogo universiteta. Kazan, YaZ Publ., pp. 102-108. (in Russian).

Nedashkovsky L.F., Rakushin A.I., 1998. Bronze mirrors from the second half of Xth to the XIVth century from the Saratov region museums. Tatarskaya arkheologiya, no. 2 (3), pp. 87-108. (in Russian).

Nedashkovsky L.F., Shigapov M.B., 2015. Wearingapparel components and mirrors from Hmelevka I settlement. Uchenye zapiski Kazanskogo universiteta. Seriia "Gumanitarnye nauki», vol. 157, book 3, pp. 34-45. (in Russian).

Nedashkovsky L.F., Shigapov M.B., 2016a. Metal wares from Hmelevka I settlement. Uchenye zapiski Kazanskogo universiteta. Seriia «Gumanitarnye nauki», vol. 158, book 3, pp. 653-665. (in Russian).

Nedashkovsky L.F., Shigapov M.B., 2016b. Finds from Hmelevka I settlement. Problemy Arkheologii Nizhnego Povolzhia: materialy V Mezhdunar. Nizhnevolzh. arkheol. konf., 15-18 noiab. 2016 g. Elista, Izd-vo Kalmytskogo un-ta, pp. 242-247. (in Russian).

Polyakova G.F., 1996. Wares from non-ferrous and precious metals. Gorod Bolgar: Remeslo metallurgov, kuznetsov, liteyshchikov. Kazan', Tatpoligraf Publ., pp. 154-268. (in Russian).

Rudenko K.A., 2004. Metallic mirrors of the Golden Horde time from the collection of the National 
museum of the Republic of Tatarstan. Tatarskaya arkheologiya, no. 1-2 (12-13), pp. 111-156. (in Russian).

Rudenko K.A., 2011. The cities and villages of Bulgar ulus of the Golden Horde (characteristics of material culture). Tatarskaya arkheologiya, no. 1-2 (20-21), pp. 32-151. (in Russian).

Savchenkova L.L., 1996. Ferrous metal of Bolgar. Typology. Gorod Bolgar: Remeslo metallurgov, kuznetsov, liteyshchikov. Kazan', Tatpoligraf Publ., pp. 5-88. (in Russian).

Fyodorov-Davydov G.A., 1966. The nomads of Eastern Europe under the sway of the Golden Horde khans. Archaeological monuments. Moscow, Izd-vo Mosk. un-ta. 274 p. (in Russian).
Fyodorov-Davydov G.A., 2001. The Golden Horde cities of the Volga region: Pottery. Trade. Way of life. Moscow, Izd-vo MGU. 254 p. (in Russian).

Fyodorov-Davydov G.A., Vayner I.S., Guseva T.V., 1974. Investigations of three manors in eastern suburb of New Saray (Tsarevskoe site). Goroda Povolzh'ya v srednie veka. Moscow, Nauka Publ., pp. 89-131. (in Russian).

Shnaydshteyn E.V., 1979. Excavations of barrows in site Guva. Arkheologicheskie pamyatniki Kalmytskoy stepi. Elista, Kalm. NII istorii, filosofii i ekonomiki, pp. 55-68. (in Russian).

Nedashkovsky L.F., 2004. Ukek: The Golden Horde city and its periphery / BAR. International Series, 1222. Oxford, Archaeopress Publ. 253 p.

\section{Information about the Authors}

Leonard F. Nedashkovsky, Doctor of Sciences (History), Associate Professor, Department of History of Tatarstan, Archaeology and Ethnology, Kazan (Volga region) Federal University, Kremlevskaya St., 18, 420008 Kazan, Russian Federation, Leonard.Nedashkovsky@kpfu.ru.

Marat B. Shigapov, Researcher, Institute of Archaeology named after A.Kh.Khalikov of the Academy of Sciences of the Republic of Tatarstan, Butlerova St., 30, 420012 Kazan, Russian Federation, maratshigapov@gmail.com.

\section{Информация об авторах}

Леонард Федорович Недашковский, доктор исторических наук, доцент кафедры истории Татарстана, археологии и этнологии, Казанский (Приволжский) федеральный университет, ул. Кремлевская, 18, 420008 г. Казань, Российская Федерация, Leonard.Nedashkovsky@kpfu.ru.

Марат Баязитович Шигапов, научный сотрудник, Институт археологии им. А.Х. Халикова Академии наук Республики Татарстан, ул. Бутлерова, 30, 420012 г. Казань, Российская Федерация, maratshigapov@gmail.com. 